\title{
Estimating the Direct Energy Use in Agriculture: A Case Study for Turkey
}

\author{
Fethi Şaban ÖZBEK* \\ Turkish Statistical Institute ${ }^{1}$, Agricultural Statistics Department, Ankara \\ *Corresponding author:fethiozbek@gmail.com
}

Bulletin USAMV series Agriculture 72(2)/2015

Print ISSN 1843-5246; Electronic ISSN 1843-5386

DOI 10.15835/buasvmcn-agr: 11290

\begin{abstract}
A model to estimate total direct energy use in agriculture was developed for Turkey by using the data obtained from various study reports, survey results, and administrative data. The model was applied to provide the quantification of direct energy use in Turkey agriculture for the period of 2008. Direct energy use in agriculture was estimated by direct energy use in crop production, in bovine, sheep and goats production, and in poultry production. According to the model results, total direct energy use in agriculture in Turkey for 2008 is estimated as 4862 kTEP. Diesel energy use in crop production has the highest share in total direct energy use in agriculture with $84 \%$. This is followed by electricity use for agricultural irrigation (8\%), energy use in poultry production (5\%), energy use in bovine and sheep and goats production (3\%), and energy used for heating in greenhouse production $(0.1 \%)$. Comparing total direct energy use in agriculture data of European Union (0.15 TEP ha $\left.{ }^{-1} \mathrm{yr}^{-1}\right)$ with the data obtained in this study $\left(0.12 \mathrm{TEP} \mathrm{ha}^{-1} \mathrm{yr}^{-1}\right)$, the value of Turkey was lower.
\end{abstract}

Keywords: agriculture, direct energy use, estimation model, Turkey.

\section{INTRODUCTION}

Intensive use of energy is crucial in terms of environmental problems, which question the global sustainable development, particularly $\mathrm{CO}_{2}$ and $\mathrm{NO}_{\mathrm{x}}$ emissions from fossil energy combustion (Pervanchon et al., 2002). The agriculture, which has become more energy-intensive in order to supply more food to increasing population and provide adequate nutrition (Hatırlı et al., 2005), contributes to the depletion of non-renewable energy sources and to global warming through energy-related emissions (Eurostat, 2015a).

The use of energy in agriculture is typically separated into direct energy use (e.g. use of fuels and electricity) and indirect use of energy through energy-intensive inputs, most notably fertilizer and pesticides (e.g. Beckman et al., 2013; Warwick, 2007). Direct energy use at farm level is one of the 28 agri-environmental indicators determined

\footnotetext{
\&? The opinions and contents of the article remains the responsibility of the author, not of the Turkish Statistical Institute.
}

by Eurostat (EC, 2006). Assessments of direct energy use in agriculture are also carried out by the European Environment Agency (EEA, 2015) and the Organisation for Economic Co-operation and Development (OECD, 2013). In this study, the direct energy use in agriculture is examined, and estimated by the sub-categories of agriculture.

Direct energy sources in agriculture comprise petroleum products (diesel, gasoline, burning oil, propane (LPG)), electricity, natural gas, coal, renewable energy sources (solar, biomass, wind, geothermal, hydroelectric, wave, and hydrogen energy. Petroleum products, electricity, natural gas, coal, biomass, solar, and geothermal are used as direct energy sources in Turkey agriculture (Özbek, 2009).

Direct energy use in agriculture is not only useful as indicators of the environmental pressure of agriculture at the national scale, it also helps to improve our understanding of agricultural production systems by quantifying energy 
consumption using local and regional data (e.g. Hessel, 1992; Swanton et al., 1996; Khan and Singh, 1997; Pervanchon et al., 2002; Bayramoğlu and Gündoğmuş, 2008).

The purpose of this study is twofold: first, to develop a method that allows for the estimation of the direct energy use in agriculture; and second, to apply the method to provide the quantification of direct energy use in Turkey agriculture for the period of 2008.

\section{MATERIAL AND METHODS}

A model to estimate total direct energy use in agriculture $\left(\mathrm{TE}_{\mathrm{E}}\right.$ ) was developed by using the data obtained from various study reports, survey results, and administrative data. $\mathrm{TE}_{\mathrm{E}}$ comprises direct energy use in crop production $\left(\mathrm{CP}_{\mathrm{E}}\right)$, in bovine and sheep and goats production $\left(\mathrm{BSG}_{\mathrm{E}}\right)$, and in poultry production $\left(\mathrm{PP}_{\mathrm{E}}\right)$.

In Turkey, $\mathrm{CP}_{\mathrm{E}}$ is separated into diesel energy used for agricultural equipment and machineries, electricity energy use for irrigation, and energy used for heating in greenhouse production (Eq. 2) (Özbek, 2009). Diesel energy use was calculated by crop types. In the calculations, the coefficients of diesel energy use per area by crop types were estimated by dividing expenses for diesel use (Gündoğmuş ve Ekibi, 2009) by average diesel price. Electricity energy data of Turkish Electricity Distribution Corporation (TEDAS) was used in the calculation of electric energy use. In the calculation of energy used for heating in greenhouse production, national data of wood consumption per unit area for heating in greenhouse production () (Bayramoğlu ve Gündoğmuş, 2008) was used.

$$
C P_{E}=\sum\left(k_{i} * a_{i}\right)+E+\left(k_{g h} * a_{g h}\right)
$$

Equation 1.

$\mathrm{k}_{\mathrm{i}}$ : diesel energy use ratio for crop i (MJ/da)

ai : cropped area for crop i (da)

E : electricity energy use for irrigation (MJ)

$\mathrm{k}_{\mathrm{gh}} \quad$ : energy used for heating in greenhouse production per area (MJ/da)

$\mathrm{a}_{\mathrm{gh}} \quad$ : cropped area of greenhouse (da)

$\mathrm{BSG}_{\mathrm{E}}$ and $\mathrm{PP}_{\mathrm{E}}$ were estimated by using survey data of Agricultural Holdings Economic Structure Survey (TEYA). The coverage of this survey was the whole country, and the period was the crop year of 2008 (TurkStat, 2009). Two-stage cluster sampling method was used in the sampling of the survey. The first stage was the selection of settled area, and the second stage was the selection of agricultural holdings. The survey results of 685 agricultural holdings only engaged in bovine production, 321 agricultural holdings only engaged in sheep and goats production, 45 agricultural holdings only engaged in laying hen production, and 556 agricultural holdings only engaged in broiler production were used in the estimations.

The electricity is used for lightening and operating agricultural equipment and machineries in bovine, sheep and goats production in Turkey (Özbek, 2009). It was assumed that only the electricity was used as energy source in $\mathrm{BSG}_{\mathrm{E}}$ as diesel used for animal transportation in the farm was assumed as negligible, and diesel used for forage production and transportation was included in $\mathrm{CP}_{\mathrm{E}^{*}}$. Also, the transportation of farm animals out of farm is included in freight transport by road in transportation sector instead of agricultural sector according to Statistical Classification of Economic Activities in the European Community (NACE) (Eurostat, 2015b)

$\mathrm{BSG}_{\mathrm{E}}$ was calculated by multiplying electricity energy use ratios by the number of animals (Eq. 2). The electricity energy use ratios were estimated by animal groups. For this, the agricultural holdings were separated into 4 groups by the number of animals ([1-9], [10-19], [20-49], 50+). The electricity energy use ratios were calculated for each group by dividing the total monetary value of electricity use obtained from TEYA by the average electricity price.

$B S G_{E}=\sum_{i=1}^{n=4} k_{B_{-} i} * n_{B_{-} i}+\sum_{i=1}^{n=4} k_{S G_{-} i} * n_{S G_{-} i}$

Equation 2.

$\mathrm{k}_{\mathrm{B}_{-} \mathrm{i}}$ : electricity energy use ratio in bovine production by the animal groups (MJ/head)

$\mathrm{n}_{\mathrm{B} i \mathrm{i}} \quad$ : number of bovine by the animal groups (head)

$\mathrm{k}_{\mathrm{SG} \mathrm{i}} \quad$ : electricity energy use ratio in sheep and goats production by the animal groups (MJ/ head)

$\mathrm{n}_{\mathrm{SG}} \mathrm{i} \quad$ : number of bovine by the animal groups (head) 
$\mathrm{PP}_{\mathrm{E}}$ was calculated by multiplying energy use ratios by the number of animals (Eq. 3 ). While the quantities of diesel, electricity, natural gas, and coal uses were calculated by dividing total monetary value of each energy source obtained from TEYA by average prices of them, the TEYA results were directly used for the quantities of wood and LPG use.

$P P_{E}=k_{b r} * n_{b r}+k_{l h} *\left(n_{l h}+n_{o p}\right)$

Equation 3.

$\mathrm{k}_{\mathrm{br}}$ : energy use ratio in broiler production (MJ/ head)

$\mathrm{n}_{\mathrm{br}}$ : number of broilers (head) $\mathrm{k}_{\mathrm{lh}}$ : energy use ratio in laying hen production (MJ/ head)

$\mathrm{n}_{\mathrm{lh}}$ : number of laying hen (head)

$\mathrm{n}_{\mathrm{op}}$ : number of other poultry (head)

The energy conversion coefficients used in the study for converting the use amount of energy sources to the common energy unit (MJ) are presented in Table 1.

\section{RESULTS AND DISCUSSION}

According to the model results, $\mathrm{TD}_{\mathrm{E}}$ in Turkey for 2008 is 4862 kTEP. Diesel energy use in crop production has the highest share in $\mathrm{TD}_{\mathrm{E}}$ with $84 \%$. This is followed by electricity use for agricultural

Table 1. Energy conversion coefficients

\begin{tabular}{cccc}
\hline Energy Source & Coefficient & Energy Source & Coefficient \\
\hline Electricity & $3.6(\mathrm{MJ} / \mathrm{KWh})$ & Natural gas & $34.54\left(\mathrm{MJ} / \mathrm{m}^{3}\right)$ \\
\hline Wood & $12.56(\mathrm{MJ} / \mathrm{kg})$ & Gasoline & $38.71(\mathrm{MJ} / \mathrm{lt})$ \\
\hline Coal & $25.54(\mathrm{MJ} / \mathrm{kg})$ & Diesel & $35.45(\mathrm{MJ} / \mathrm{lt})$ \\
\hline $\mathrm{LPG}$ & $45.64(\mathrm{MJ} / \mathrm{kg})$ & & \\
\hline Source: Turkey General Directorate of Electric Power Resources Survey and Development Administration, 1995
\end{tabular}

Table 2. Direct energy use by agricultural activities

\begin{tabular}{llccc}
\hline $\begin{array}{l}\text { Direct energy use by } \\
\text { agricultural activities }\end{array}$ & Model* & $\begin{array}{c}\text { Energy } \\
\text { use (MJ) }\end{array}$ & $\begin{array}{c}\text { Energy } \\
\text { use (1000 } \\
\text { TEP) }\end{array}$ & $\begin{array}{c}\text { Share in } \\
\text { TEE (\%) }\end{array}$ \\
\hline $\begin{array}{l}\text { Diesel energy use in crop } \\
\text { production }\end{array}$ & $\sum\left(k_{i} * a_{i}\right)$ & $17.1 \mathrm{E}+10$ & 4093 & 84 \\
\hline $\begin{array}{l}\text { Electricity energy use for } \\
\text { agricultural irrigation }\end{array}$ & $E$ & $1.7 \mathrm{E}+10$ & 396 & 8 \\
\hline $\begin{array}{l}\text { Energy used for heating in } \\
\text { greenhouse production }\end{array}$ & $\left(k_{g h} * a_{g h}\right)$ & $2.8 \mathrm{E}+8$ & 7 & 0.1 \\
\hline $\begin{array}{l}\text { Total energy use in crop } \\
\text { production }\end{array}$ & $C P_{E}=\sum\left(k_{i} * a_{i}\right)+E+\left(k_{g h} * a_{g h}\right)$ & $18.8 \mathrm{E}+10$ & 4495 & 92 \\
\hline $\begin{array}{l}\text { Energy use in bovine, sheep } \\
\text { and goats production }\end{array}$ & $B S G_{E}=\sum_{i=1}^{n=4} k_{B_{-} i} * n_{B_{-} i}+\sum_{i=1}^{n=4} k_{S G_{-} i} * n_{S G_{-} i}$ & $58.8 \mathrm{E}+8$ & 140 & 3 \\
\hline $\begin{array}{l}\text { Energy use in poultry } \\
\text { production }\end{array}$ & $P P_{E}=k_{b r} * n_{b r}+k_{l h} *\left(n_{l h}+n_{o p}\right)$ & $94.9 \mathrm{E}+8$ & 227 & 5 \\
\hline $\begin{array}{l}\text { Total energy use in } \\
\text { agriculture }\end{array}$ & $T E_{E}=C P_{E}+B S G_{E}+P P_{E}$ & $20.4 \mathrm{E}+10$ & 4862 & 100 \\
\hline
\end{tabular}

* For abbreviations, see Section 2. 
irrigation (8\%), energy use in poultry production (5\%), energy use in bovine and sheep and goats production (3\%), and energy used for heating in greenhouse production $(0.1 \%)$. The models developed to estimate direct energy use in subcategories of agriculture, and the amounts of direct energy use are presented in Table 2. Diesel energy use in cereals and other crop products accounts for $77 \%$ of diesel energy use in crop production.

The cereals and other crop products group is followed by fruits, beverage and spice crops (15\%), and vegetables (8\%).

The highest energy use per head in bovine production was observed in the agricultural holdings with 50+ number of bovines. This group is followed by the agricultural holdings with
[1-9], [20-49], and [10-19] number of bovines, respectively. In sheep and goats production, the highest energy use per head was observed in the agricultural holdings with [1-9] number of sheep and goats. This group is followed by the agricultural holdings with [10-19], [20-49], and $50+$ number of sheep and goats, respectively. Total energy use in bovine production is higher than that in sheep and goats production in Turkey for 2008 (Table 3).

In $\mathrm{PP}_{\mathrm{E}}$ the coal has the highest energy use ratio among the energy sources. The coal is followed by LPG, electricity, natural gas, diesel, and wood (Table 4). The weighted energy use ratio for poultry (38.1 MJ/head) is noticeably lower than

Table 3. Energy use ratios and energy use by animal groups in bovine, sheep and goats production

\begin{tabular}{cccccc}
\hline $\begin{array}{c}\text { Energy use / Animal groups by } \\
\text { the number of bovines (heads) }\end{array}$ & $1-9$ & $10-19$ & $20-49$ & $50+$ & $\begin{array}{c}\text { Weighted } \\
\text { /Total }\end{array}$ \\
\hline $\begin{array}{c}\text { Energy use ratio in bovine } \\
\text { production (MJ/head) }\end{array}$ & 426.1 & 110.4 & 208.7 & 592.0 & 320.6 \\
\hline $\begin{array}{c}\text { Energy use ratio in sheep and } \\
\text { goats production (MJ/head) }\end{array}$ & 750.4 & 533.2 & 29.0 & 42.9 & 80.0 \\
\hline $\begin{array}{c}\text { Energy use in bovine production } \\
\text { (MJ) }\end{array}$ & $26.4 \mathrm{E}+8$ & $3.0 \mathrm{E}+8$ & $3.4 \mathrm{E}+8$ & $2.3 \mathrm{E}+8$ & $35.1 \mathrm{E}+8$ \\
\hline $\begin{array}{c}\text { Energy use in sheep and goats } \\
\text { production (MJ) }\end{array}$ & $5.1 \mathrm{E}+8$ & $7.5 \mathrm{E}+8$ & $1.7 \mathrm{E}+8$ & $9.3 \mathrm{E}+8$ & $23.7 \mathrm{E}+8$ \\
\hline $\begin{array}{c}\text { Total energy use in bovine, } \\
\text { sheep and goats production } \\
\text { (MJ) }\end{array}$ & $31.6 \mathrm{E}+8$ & $10.6 \mathrm{E}+8$ & $5.0 \mathrm{E}+8$ & $11.6 \mathrm{E}+8$ & $58.8 \mathrm{E}+8$ \\
\hline
\end{tabular}

Table 4. Energy use ratios and energy use by sources in poultry production

\begin{tabular}{ccccccccc}
\hline & Broiler production & \multicolumn{2}{c}{ Laying hen production } & $\begin{array}{c}\text { Other poultry } \\
\text { production }\end{array}$ & Total \\
\hline Energy use $\begin{array}{c}\text { Energy use } \\
\text { ratio (MJ/ } \\
\text { head) }\end{array}$ & $\begin{array}{c}\text { Energy use } \\
\text { (MJ) }\end{array}$ & $\begin{array}{c}\text { Energy use } \\
\text { ratio (MJ/ } \\
\text { head) }\end{array}$ & $\begin{array}{c}\text { Energy use } \\
\text { (MJ) }\end{array}$ & $\begin{array}{c}\text { Energy use } \\
\text { ratio (MJ) } \\
\text { head) }\end{array}$ & $\begin{array}{c}\text { Energy use } \\
\text { (MJ) }\end{array}$ & $\begin{array}{c}\text { Weighted } \\
\text { ratio (MJ/ } \\
\text { head) }\end{array}$ & $\begin{array}{c}\text { Energy use } \\
\text { (MJ) }\end{array}$ \\
\hline $\begin{array}{c}\text { Natural gas } \\
\text { use }\end{array}$ & 5.8 & $10.5 \mathrm{E}+8$ & 3.2 & $2.0 \mathrm{E}+8$ & 3.2 & $15.1 \mathrm{E}+6$ & 5.1 & $12.6 \mathrm{E}+8$ \\
\hline $\begin{array}{c}\text { Electricity } \\
\text { use }\end{array}$ & 5.8 & $10.4 \mathrm{E}+8$ & 11.3 & $7.1 \mathrm{E}+8$ & 11.3 & $53.7 \mathrm{E}+6$ & 7.3 & $18.1 \mathrm{E}+8$ \\
\hline Coal use & 9.2 & $16.6 \mathrm{E}+8$ & 26.8 & $17.0 \mathrm{E}+8$ & 26.8 & $1.3 \mathrm{E}+8$ & 14.0 & $34.9 \mathrm{E}+8$ \\
\hline LPG use & 7.4 & $13.5 \mathrm{E}+8$ & 13.6 & $8.6 \mathrm{E}+8$ & 13.6 & $64.7 \mathrm{E}+6$ & 9.1 & $22.7 \mathrm{E}+8$ \\
\hline Diesel use & 2.5 & $4.5 \mathrm{E}+8$ & 2.4 & $1.5 \mathrm{E}+8$ & 2.4 & $11.6 \mathrm{E}+6$ & 2.5 & $6.2 \mathrm{E}+8$ \\
\hline Wood use & 0.001 & $18.1 \mathrm{E}+4$ & 0.5 & $34.2 \mathrm{E}+6$ & 0.5 & $2.6 \mathrm{E}+6$ & 0.1 & $37.0 \mathrm{E}+6$ \\
\hline Total & 30.7 & $55.5 \mathrm{E}+8$ & 57.8 & $36.6 \mathrm{E}+8$ & 57.8 & $2.8 \mathrm{E}+8$ & 38.1 & $94.9 \mathrm{E}+8$ \\
\hline
\end{tabular}


the ratios for sheep and goats $(80.0 \mathrm{MJ} /$ head $)$ and bovine (320.6 MJ/head).

According to the data of direct energy use per ha utilized agricultural area (UAA) in EU countries for 2008 (Eurostat, 2015c), the maximum value was observed in Netherlands with $1.63 \mathrm{TEP}^{\mathrm{ha}} \mathrm{h}^{-1}$ $\mathrm{yr}^{-1}$ and the minimum value was obtained in Malta with $0.00 \mathrm{TEP} \mathrm{ha}^{-1} \mathrm{yr}^{-1}$ (Fig. 2). The value of direct energy use per ha UAA in agriculture of Turkey (0.12 TEP ha-1 $\left.\mathrm{yr}^{-1}\right)$ was lower than the average EU value $\left(0.15 \mathrm{TEP} \mathrm{ha}^{-1} \mathrm{yr}^{-1}\right)$.
This study shows that diesel is the most important element of the direct energy use in Turkey agriculture (Table 2), like in many countries (Eurostat, 2015c). It was highlighted that diesel use efficiency could be improved by different practices and technologies (e.g. Biggs and Giles, 2013; Warwick, 2007). The other important element of the direct energy use in agriculture is electricity used for irrigation. Globally, 70\% fresh water is withdrawn for irrigation, and irrigation uses more than $90 \%$ of consumptive water to

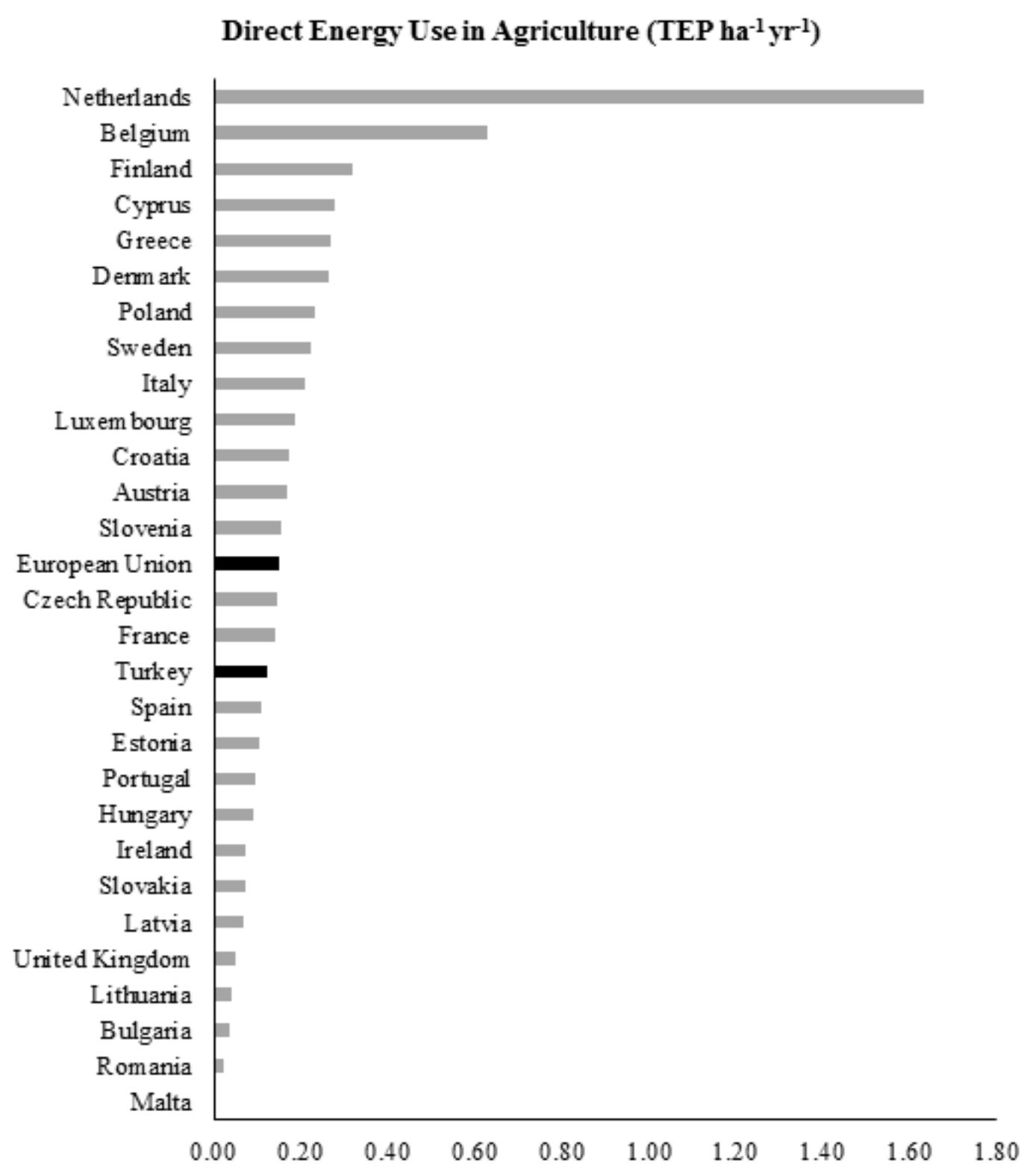

Figure 1. Direct energy use values of Turkey and EU Countries in 2008 (Eurostat, 2015c). No data is available for Germany. EU excludes Germany data. 
produce $40 \%$ of the global harvest (Rothausen and Conway, 2011). Improving energy use efficiency for irrigation through using energy-efficient equipment and designs are important to minimize the amount of unnecessary water use, in addition to the energy savings (Li et al., 2013; Extension, 2015). For this reasons, setting up schemes for optimising diesel and electricity use in agriculture has gained in importance in order to improve the socio economic and environmental sustainability in the agricultural sector.

The results of energy use ratios by animal groups show that energy use ratio per head in the agricultural holdings decreases with decreasing number of sheep and goats. This indicates that the mechanization does not increase with increasing number of sheep and goats. The main reason for this is that in Turkey, milking is done by hand as a large part of the sheep and goats are bred in small herds, and milk yield levels are not too high (Anonymous, 2015). On the contrary, it is observed that the highest energy use ratio per head is estimated in the agricultural holdings with high number of bovines (50+) (Table 3). The main reason for this is that the mechanization in dairy cows production increased for the big agricultural holdings in recent years due to the state supports for milking parlours, and milking machinery (ARDSI, 2015; Saglam et al., 2015).

ETKB (2009), estimated national energy use in agriculture as 3610 kTEP for Turkey for the year of 2006. This result is convenient with the results of this study (4862 kTEP) as the energy use in Turkey agriculture tends to increase with years. Hatırl et al. (2005) found diesel and electricity energy use per UAA in Turkey agriculture as $0.195 \mathrm{TEP} / \mathrm{ha}$ for the year of 2000. This value is higher than the value estimated in this study (0.124 TEP/ha). The main reason for this difference is twofold they (i) used the literature values for diesel use whereas the survey data was used in this study (ii) could not to separate the consumption of electricity for purposes other than agricultural production due to lack of data.

The main reason for low direct energy use in agriculture in the countries in Eastern Europe is the low intensification level in agriculture in these countries. The countries with high intensification level in agriculture mostly in Western and Northern Europe use high direct energy in agriculture except for United Kingdom and Ireland. The main reason for low direct energy use per hectare in agriculture in these countries is that these countries have the highest grassland/cropland ratio in Europe. Comparing total direct energy use in agriculture data of European Union (0.15 TEP ha-1 $\mathrm{yr}^{-1}$ ) with the data obtained in this study ( $\left.0.12 \mathrm{TEP} \mathrm{ha}^{-1} \mathrm{yr}^{-1}\right)$, the value of Turkey was close to the EU value as a result of different intensification levels among the regions of Turkey (Fig. 1).

There is a lack of information on the amount of energy used in Turkey agricultural sector. In studies carried out to date, the energy used in agriculture has been demonstrated for certain regions as part of a product or groups of product. This study provides important contributions to overcome the lack of available information on the amount of energy used in agriculture by calculating separately for each sub-category of agricultural activities.

\section{REFERENCES}

1. Anonymous (2015). Sheep milking, http://www. tarimkutuphanesi.com/KOYUNLARIN _SAGIMI_00168. html (accessed 27.04.2015).

2. ARDSI (2015). Signed agreements, Agriculture and Rural Development Institution, http://www.tkdk.gov.tr/ ImzalananSozlesmeler.aspx (accessed: 28.04.2015).

3. Bayramoğlu Z, Gündoğmuș E (2008). The effect of EurepGAP standarts on energy input use: A comparative analysis between certified and uncertified greenhouse tomato producers in Turkey, Journal of Energy Conversion and Management, 50(2009), 52-56.

4. Beckman J, Borchers A, Jones CA (2013). Agriculture's Supply and Demand for Energy and Energy Products. Economic Information Bulletin Number 112. USDA.

5. Biggs L, Giles D (2013). Current and future agricultural practices and technologies which affect fuel efficiency. Intelligent Energy Europe - European Commission.

6. EC (2006). Development of agri-environmental indicators for monitoring the integration of environmental concerns into the common agricultural policy. Communication from the Commission to the Council and the European Parliament. COM(2006) 508 final. Commission of the European Communities, Brussels. Retrieved from: http://eur lex.europa.eu/LexUriServ/LexUriServ. do?uri=COM:2006:0508:FIN:EN:PDF (accessed 03.03.2015).

7. EEA (2015). http://www.eea.europa.eu/data-and-maps/ indicators/final-energy-consump tion- by-sector-8/ assessment-2 (accessed 23.04.2015).

8. ETKB (2009), http://www.enerji.gov.tr/EKLENTI_VIEW/ index.php/raporlar/raporVeri Gir /4043/2 (accessed 20 Ekim 2009). 
9. Eurostat (2015a). http://ec.europa.eu/eurostat/ statistics-explained/index.php/Agri-environmental_ indicator_-_energy_use (accessed 25.03.2015).

10. Eurostat (2015b). http://ec.europa.eu/eurostat/ramon/ nomenclatures/index.cfm?TargetUrl = DSP_NOM_DTL_ VIEW\&StrNom=NACE_REV2\&StrLanguageCode=EN\&Int PcKey $=18512654 \&$ IntKey=18512684\&StrLayoutCode= HIERARCHIC\&IntCurrentPage=1 (accessed 30.03.2015).

11. Eurostat (2015c). Simplified energy balance. http:// appsso.eurostat.ec.europa.eu/nui/ show.do ? dataset =nrg_100a\&lang=en (accessed 10.04.2015).

12. Extension (2015). http://www.extension.org/ pages $/ 27775 /$ introduction-to-energy-efficientirrigation\#.VTEb_iHtlBd (accessed 15.04.2015).

13. Gündoğmuş E (2009). Karayolları Genel Müdürlüğü'nce çoğunluğu 2008-2009 yılları arasında çeşitli bölgelerde yürütülen taşınmaz mal değerlemesi mühendislik işi kapsamında hazırlanan arazi değerleme raporları (24 il), Ankara.

14. Hatırlı SA, Özkan B, Fert C, (2005). An Econometric Analysis of Energy Input-Output in Turkish Agriculture, Renewable and Sustainable Energy Reviews, 9(6), 608623.

15. Hessel, ZR (1992). Energy and alternatives for fertiliser and pesticide use. In: Flick RC, editor. Energy in farm production. Energy in world agriculture, vol. 6, New York: Elsevier Science Publishing; p. 177-201.

16. Khan MA, Singh G (1997). Energy inputs and potential for agricultural production in Western Pakistan, Agricultural Systems, 54(3), 341-356.
17. Li C, Wang Y, Qiu G (2013). Water and Energy Consumption by Agriculture in the Minqin Oasis Region, J Integr Agr 12(8), 1330-1340.

18. OECD (2013). OECD Compendium of Agrienvironmental Indicators. OECD Publishing. doi:10.1787/9789264186217-en.

19. Özbek (2009). Developing estimation model for energy consumption in agriculture sector, TurkStat Expertise Thesis, Ankara.

20. Pervanchon F, Bockstaller C, Girardin P (2002). Assessment of energy use in arable farming systems by means of an agro-ecological indicator: the energy indicator, Agricultural Systems, 72 (2002), 149-72.

21. Rothausen SGSA, Conway D (2011). Greenhouse-gas emissions from energy use in the water sector. Nature Climate Change, 1, 210-219.

22. Sağlam C, Kuş ZA, Yllmaz S (2015). Evaluation of Milking Facilities and Machinery in Dairy Operations of Central Anatolia. Turkish Journal of Agriculture - Food Science and Technology, 3(2): 63-66.

23. Swanton CJ, Murphy SD, Humea DJ, Clement DR (1996). Recent improvements in the energy efficiency of agriculture: case studies from Ontario, Canada, Agriculturul systems, 52 (1996), 399-418.

24. Turkstat (2009). Agricultural Holdings Economic Structure Survey Handbook, TurkStat, Ankara

25. Warwick HRI (2007). Direct energy use in agriculture: opportunities for reducing fossil fuel inputs. Final report to Defra. 